\title{
SOBRALIA QUINATA, A NEW SPECIES IN SECTION GLOBOSAE
}

\author{
ROBERT L. DRESSLER
}

Missouri Botanical Garden, Florida Museum of Natural History, Marie Selby Botanical Gardens
Mailing address: 21305 NW 86th Ave., Micanopy, Florida 32667. rdressl@ nersp.nerdc.ufl.edu

Resumen. Hay varios especímenes de una Sobralia de la Sección Globosae colectados en Costa Rica, pero no se han podido identificar con certeza por la mala conservación de las flores. Ahora la floración de una planta en el Jardín Botánico Lankester permite la descripción de la planta como una nueva especie, $S$. quinata.

Key words / Palabras Clave: Orchidaceae, Sobralia Sect. Globosae, Sobralia quinata, Costa Rica.

At first, the Panamanian specimens of Sobralia Section Globosae were identified as S. candida (Poepp. \& Endl.) Rchb.f. and the Costa Rican specimens as $S$. lancea Garay. While the description of the Panamanian specimens as $S$. nutans was in press (Dressler 2002), I was fortunate to see a Colombian plant in flower at Finca Drácula, in Chiriquí. Having a definite V-shaped basal callus, this would seem to be S. pardalina Garay. Only a few days later, I saw the Costa Rican plant in flower, and it is clearly neither S. lancea nor S. pardalina, differing from both these species in the presence of 5 keels that reach well onto the isthmus of the lip. It is here described as Sobralia quinata.

Sobralia quinata Dressler, sp. nov.

TYPE: Costa Rica. Cartago: Turrialba, Moravia de Chirripó, Quebrada Tsipirí, 948'N 8323'W, 1090 m, on steep slope along the Quebrada, lower montane rain forest, primary vegetation, 26 Apr. 2002, F. Pupulin, H. Montealegre, M. Bonilla \& J. C. Cervantes 3644 (holotype, USJ).

FIG. 1

Similis Sobraliae nutanti Dressler, sed planta et flore parvioribus, labello ovato-pandurato quinque carinis ornato, alis columnae brevissimis.

Herb terrestrial or epiphytic, caespitose, roots 3-5 $\mathrm{mm}$ in diameter, stems $42-50 \mathrm{~cm} \times 2-3 \mathrm{~mm}$. Leaves 17-25 x 0.9-2.1 cm, lanceolate, acuminate. Inflorescence terminal, floral bracts ca. $18 \times 5-6 \mathrm{~mm}$, lance-ovate, subacute, bract cluster gradually elongating to about $4 \mathrm{~cm}$, ovary and pedicel about $17 \mathrm{~mm}$. Sepals and petals pale green, blade of lip white with magenta spots, outer keels with magenta margins. Sepals 25-26 x 6.4-7 mm, narrowly elliptic, apiculate. Petals 25-27 × 6-6.5 mm, narrowly elliptic, apiculate. Lip ca. $25 \times 13 \mathrm{~mm}$, ovate-pandurate, basally clasping column, shallowly 3-lobed, with 5 keels, these reaching 15-18 mm from base, outer keels ca. $12 \times 1 \mathrm{~mm}$, undulate, inner keels $c a .14 \times 1.5 \mathrm{~mm}$, all ending in slightly higher lobules, lateral lobes ca. 2-2.5 x 6-7 $\mathrm{mm}$, low, rounded, isthmus $c a .9 \mathrm{~mm}$ wide, midlobe subcuadrate, undulate, shallowly retuse and apiculate, ca. $11 \mathrm{~mm}$ wide. Column ca. $10 \mathrm{~mm}$ long, wings toothlike, $c a$. 0.8-1 mm. Capsule 7-7.5 x 0.8-1 cm.

Other SPecimens Seen: Costa Rica. Alajuela: San Ramón, Reserva Forestal, a orillas de río dentro del bosque, 18 feb. 1983, Carvajal 353 (MO, SEL) 1400 m, 17 nov. 2002, J. F. Morales 8873 (INB); San José: Cantón de Vázquez de Coronado, Parque Nac. Braulio Carrillo, along trail from S.J.-Limón Hwy to Rio Hondura, Bajo La Hondura; about $5 \mathrm{~km}$ below tunnel, in secondary forest, $10^{\circ} 04^{\prime} 10^{\prime \prime} \mathrm{N} 83^{\circ} 59^{\prime} 20^{\prime \prime} \mathrm{W}, 1250 \mathrm{~m}$., 18 Dec. 1990, S. Ingram, K. Ferrell 813 (INB, SEL); La Hondura, 15 Mar. 1924, P. C. Standley 37573 (AMES).

In Sobralia quinata the lip is distinctly 5-keeled, and the keels reach well beyond the lateral lobes. Sobralia lancea and S. pardalina have the lip more markedly pandurate, with the apical portion more or less hastate, and apparently have only 2 keels that reach only to the isthmus. I have seen little good material of the South American species, and the features given in the key below are from the the treatment in the Flora of Ecuador (Garay 1978). While $S$. quinata has only five keels, the outer keels 

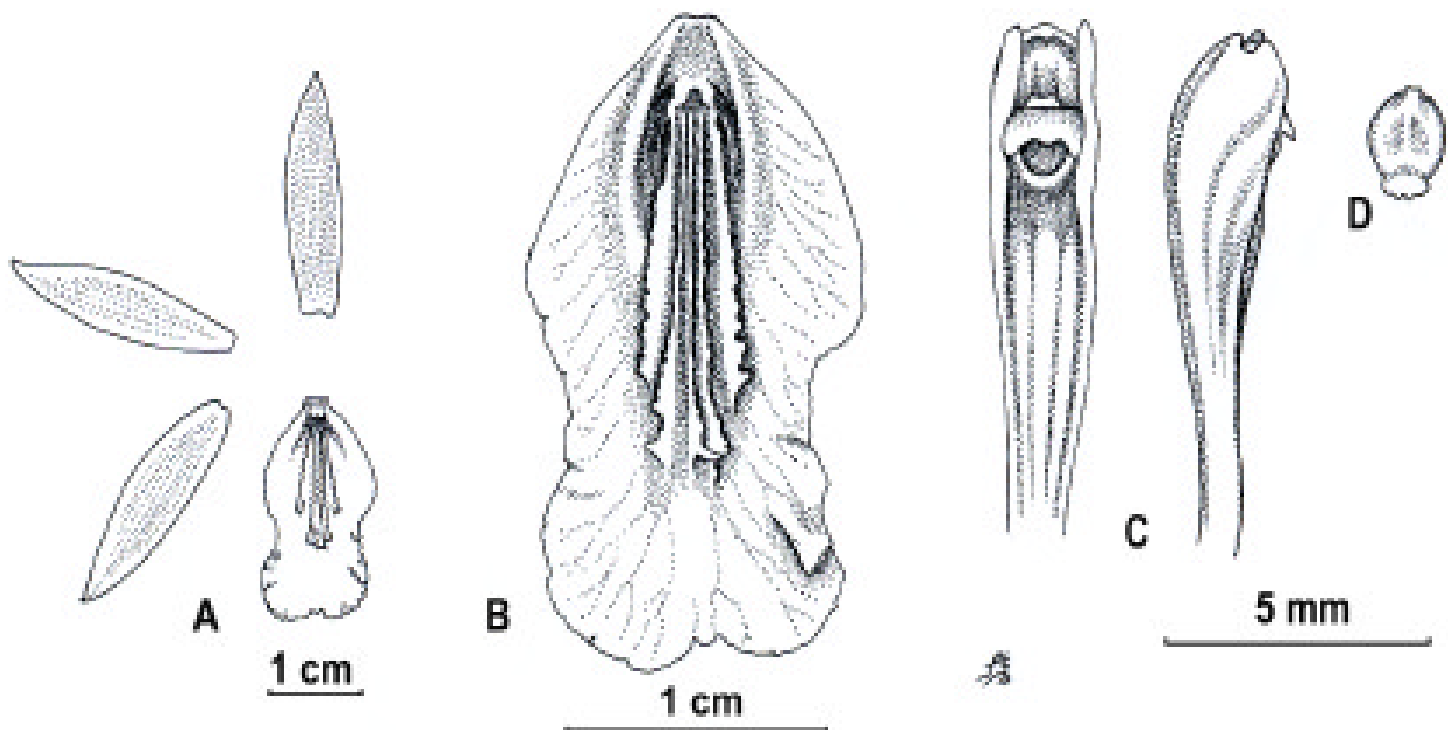

Fig. 1. Sobralia quinata Dressler. A - floral parts, flattened. B - Lip, flattened. C - Column ventral and lateral views. D - Anther. Drawn from type specimen.

are higher throughout, and the three lower keels have higher distal lobes, suggesting a close relationship with the larger S. nutans, which has 7 keels. Sobralia quinata also resembles $S$. nutans in that the flowers are pendent and face the stem. The epithet quinata refers to the presence of five keels on the lip.

\section{Revised Key to the SPecies of Sobralia Section Globosae}

1. Lip ovate, subovate or shallowly pandurate, with 5-7 keels, these much longer than lateral lobes 2

2. Lip with 7 keels, 2 outer keels on each side prominent, dentate throughout, 3 inner keels low basally, with prominent, erect apical lobules Sobralia nutans [Panamá]

2. Lip with 5 keels

3. Lip with outer keels undulate, inner keels lower but with distal lobules; lip ovate-pandurate

Sobralia quinata [Costa Rica]

3. Lip with 5 low keels, these distally dentate; lip distally shallowly 3-lobed

Sobralia candida [Venezuela, Colombia, Ecuador, Peru, Bolivia]

1. Lip clearly pandurate, keels about half length of lip; outer keels undulate, inner keels lower and shorter (if present)

4. Lip with a V-shaped basal callus; leaves thin, membranous ........ Sobralia pardalina [Colombia, Ecuador]

4. Lip without basal callus; leaves subcoriaceous Sobralia lancea [Colombia, Ecuador]

\section{ACKNOWLEDGMENTS}

I am very grateful to Franco Pupulin, for help with the Latin diagnosis, and especially for giving me the opportunity to know this species as a living, flowering plant.

\section{Literature Cited}

Dressler, R.L 2002. The major sections or groups within Sobralia, with four new species from Panama and Costa Rica, S. crispissima, S. gloriana, S. mariannae and S. nutans. Lankesteriana 5: 9-15.

Garay, L.A. 1978. Orchidaceae: Cypripedioideae, Orchidoideae, Neottioideae. In G. Harling \& B. Sparre (Eds.), Flora of Ecuador no. 9. 